\title{
Patológiás myopia talaján kialakult érújdonképződés intravitrealis ranibizumabkezelése
}

\author{
Lukács Regina dr. ${ }^{1}$ - Sándor Gábor dr. ${ }^{2}$ - Resch Miklós dr. ${ }^{2}$ \\ Szabó Antal dr. ${ }^{2}$ - Barcsay György dr. ${ }^{2}$ - Ecsedy Mónika dr. ${ }^{2}$ \\ Szepessy Zsuzsanna dr. ${ }^{2}$ - Nagy Zoltán Zsolt dr. ${ }^{2}$. Papp András dr. ${ }^{2}$ \\ ${ }^{1}$ Pest Megyei Flór Ferenc Kórház, Kistarcsa \\ ${ }^{2}$ Semmelweis Egyetem, Általános Orvostudományi Kar, Szemészeti Klinika, Budapest
}

\begin{abstract}
Bevezetés: A patológiás myopia világszerte a látásvesztés egyik meghatározó oka, jelentős részben a még aktív, dolgozó korosztályt érintve. Az egyik jelentős, látást veszélyeztető komplikáció patológiás myopiában a chorioidea-neovascularisatio. Célkitüzés: A patológiás myopia talaján kialakult subfovealis érújdonképződések intravitrealis ranibizumabkezelése eredményességének vizsgálata. Módszer: Retrospektív analízisünk során 14 beteg (életkor: $61 \pm 17$ év) 14 szemén patológiás rövidlátás talaján kialakult subfovealis érújdonképződéseket kezeltünk intravitrealis ranibizumabbal, szükség szerinti adagolási móddal. Vizsgáltuk a legjobb korrigált távoli látóélesség, a chorioidea-neovascularisatiós laesio magasságának változását és a beadott injekciók számát. Eredmények: A legjobb korrigált látóélesség a kiindulási 55,8 $\pm 19,3$ betưról az első év végére $64,8 \pm 15,5$ betüre $(\mathrm{p}=0,0414)$, a követési idő végére $62,6 \pm 16,3$ betűre ( $\mathrm{p}=0,2896)$ javult. Az átlagos követési idő $19,7 \pm 23,9$ hónap, az átlagos injekciószám 2,8 $\pm 2,1$ volt. Négy szemen a látóélesség a kezelés ellenére tovább romlott. Következtetések: Az intravitrealis ranibizumab a patológiás rövidlátás talaján kialakult érújdonképződések hatékony kezelési módja. Néhány szemen a kezelés ellenére tovább romlik a látóélesség. Orv. Hetil., 2017, 158(15), 579-586.
\end{abstract}

Kulcsszavak: patológiás myopia, chorioidea-neovascularisatio, intravitrealis injekció, ranibizumab

\section{Intravitreal ranibizumab therapy for choroidal neovascularization secondary to pathological myopia}

Introduction: Pathological myopia is one of the leading causes of vision loss worldwide, especially among young people of working age. Choroidal neovascularization is one of the most important cause of visual impairment in pathological myopia. Aim: To evaluate the efficacy of intravitreal ranibizumab for the treatment of myopic choroidal neovascularization. Method: In this retrospective analysis 14 eyes of 14 patients (mean age: $61 \pm 17$ years) with myopic choroidal neovascularization were treated with intravitreal ranibizumab as needed. Best-corrected visual acuity, thickness of choroidal neovascularization lesion and the number of injections were assessed. Results: The mean visual acuity changed from $55.8 \pm 19.3$ letters to $64.8+15.5$ at 12 months $(\mathrm{p}=0.0414)$, and $62.6 \pm 16.3$ during follow-up time $(\mathrm{p}=0.2896)$. Mean follow-up time was $19.7 \pm 23.9$ months, average number of injections was $2.8 \pm$ 2.1. Visual acuity declined in four patients despite the treatment. Conclusions: Intravitreal ranibizumab is an effective therapy in pathological myopia. Some patients experience deterioration of visual acuity despite of treatment.

Keywords: pathological myopia, choroidal neovascularization, intravitreal injection, ranibizumab

Lukács, R., Sándor, G., Resch, M., Szabó, A., Barcsay, Gy., Ecsedy, M., Szepessy, Zs., Nagy, Z. Zs., Papp, A. [Intravitreal ranibizumab therapy for choroidal neovascularization secondary to pathological myopia]. Orv. Hetil., 2017, 158(15), $579-586$.

(Beérkezett: 2017. január 11.; elfogadva: 2017. február 20.) 


\section{Rövidítések}

AMD = időskori maculadegeneráció; $\mathrm{BCVA}=$ legjobb korrigált látóélesség; $\mathrm{CNV}=$ chorioidealis érújdonképződés; ETDRS $=$ a diabeteses retinopathia korai kezeléséről szóló tanulmány; MYRROR = nemzetközi, III-as fázisú, multicentrikus, randomizált, kettôs vak, placebokontrollált tanulmány a $2 \mathrm{mg}$ dózisú intravitrealis aflibercept hatásosságáról myop chorioidea-neovascularisatióban szenvedő betegeknél; OCT = optikai koherenciatomográfia; PDT = fotodinámiás terápia; PRK = fotorefraktív keratectomia; RADIANCE = randomizált, kontrollált tanulmány patológiás myopia talaján kialakult chorioidea-neovascularisatióban szenvedő betegek ranibizumabkezeléséről; REPAIR = II-es fázisú, prospektív, multicentrikus, gyártó által szponzorált tanulmány myop chorioidea-neovascularisatióban szenvedő betegek intravitrealis ranibizumabkezeléséról; VEGF = vascularis endothelialis növekedési faktor

A patológiás myopia világszerte a látásvesztés meghatározó oka, prevalenciája $0,9-3,1 \%$, a patológiás myopia okozta látásromlásé pedig 0,1-0,5\%-tól (európai tanulmányok szerint) $0,2-1,4 \%$-ig terjed (ázsiai tanulmányok szerint). A chorioidealis neovascularisatio $(\mathrm{CNV})$ gyakorisága patológiás myopiában $5,2-11,3 \%$, és $15 \%$-ban bilateralis [1]. Két európai tanulmány eredményei alapján a vakság, illetve gyengén látás 5,8 , valamint $7,8 \%$-áért a patológiás myopia tehető felelőssé $[2,3]$. Magyarországi adatok szerint a myopia a vakság negyedik leggyakoribb oka az időskori maculadegeneráció (AMD), a glaucoma és a diabeteses retinopathia után (két megye adatai alapján a vakság $10,8 \%$-ért tehető felelőssé), fiatalabb korban ez az arány még magasabb (a 0-39 éves korcsoportban 21\%, a 40-59 éves korcsoportban 14\%) [4].

Szemben a nedves típusú AMD-vel (amelyról korábbi munkáinkban számoltunk be) $[5,6]$, mely elsősorban az idős korosztályt érinti, a myopiás CNV az esetek legalább 50\%-ában 50 éves vagy annál fiatalabb korban kezdődik, azaz a még aktív, dolgozó korosztályt érinti. Ez a társadalom számára is jelentős terhet jelent $[7,8]$. Az ebben a korosztályban kialakult chorioidea-neovascularisatio hátterében 60\%-ban myopia áll, és szemben az egyéb etiológiájú CNV-kel, ez elsősorban subfovealis elhelyezkedésú [9].

$\mathrm{Az}$ irodalomban különböző kifejezések találhatók a patológiás myopiára, mint „nagyfokú myopia”, „degeneratív myopia” vagy „malignus myopia”. Nincs általánosan elfogadott definíció a patológiás myopiára, de klasszikusan általában a következő jellemzők esetén használjuk a kifejezést: legalább -6 D-ás fénytörési hiba, 26,5 mm-es vagy annál nagyobb szemtengelyhossz, patológiás szemfenéki eltérések, mint lacquer repedések vagy chorioretinalis atrophia [10-12]. A myopia új klaszszifikációját alapul véve (META-PM klasszifikáció) patológiás myopiáról beszélünk az említett osztályozásnak megfelelően legalább 2-es stádiumú myopiás maculopathia (diffúz chorioretinalis atrophia, foltos chorioretinalis atrophia, macularis atrophia), plusztünetek (lacquer repedés, myopiás CNV, Fuchs-folt) vagy hátsó staphyloma esetén $[13,14]$.

A patológiás myopiában szenvedő betegek látásromlásáért a macula, a látóidegfó és a perifériás retina különböző patológiás eltérései tehetók felelőssé. A legfontosabb szövődmények közé tartoznak többek között a hátsó staphyloma, myopiás maculopathia, myopiás chorioidea-neovascularisatio, maculalyuk, a myopiás trakciós maculopathia, a különböző perifériás degeneratív eltérések (rácsos degeneráció, retinalyuk, retinaszakadás), valamint azok szövődményei (rhegmatogen ideghártya-leválás), a papilla és peripapillaris terület elváltozásai. Ezek közül a chorioidea-neovascularisatio az egyik legjelentösebb, látást veszélyeztetô komplikáció patológiás myopiában [14] (1.a) és b) ábra).

A patológiás myopiában kialakuló $\mathrm{CNV}$ pontos patogenezise nem ismert, különböző elméletek léteznek annak kialakulására vonatkozóan $[10,15]$. A mechanikus elmélet szerint a szemgolyó anteroposterior irányú progresszív és túlzott mértékú megnyúlása mechanikus
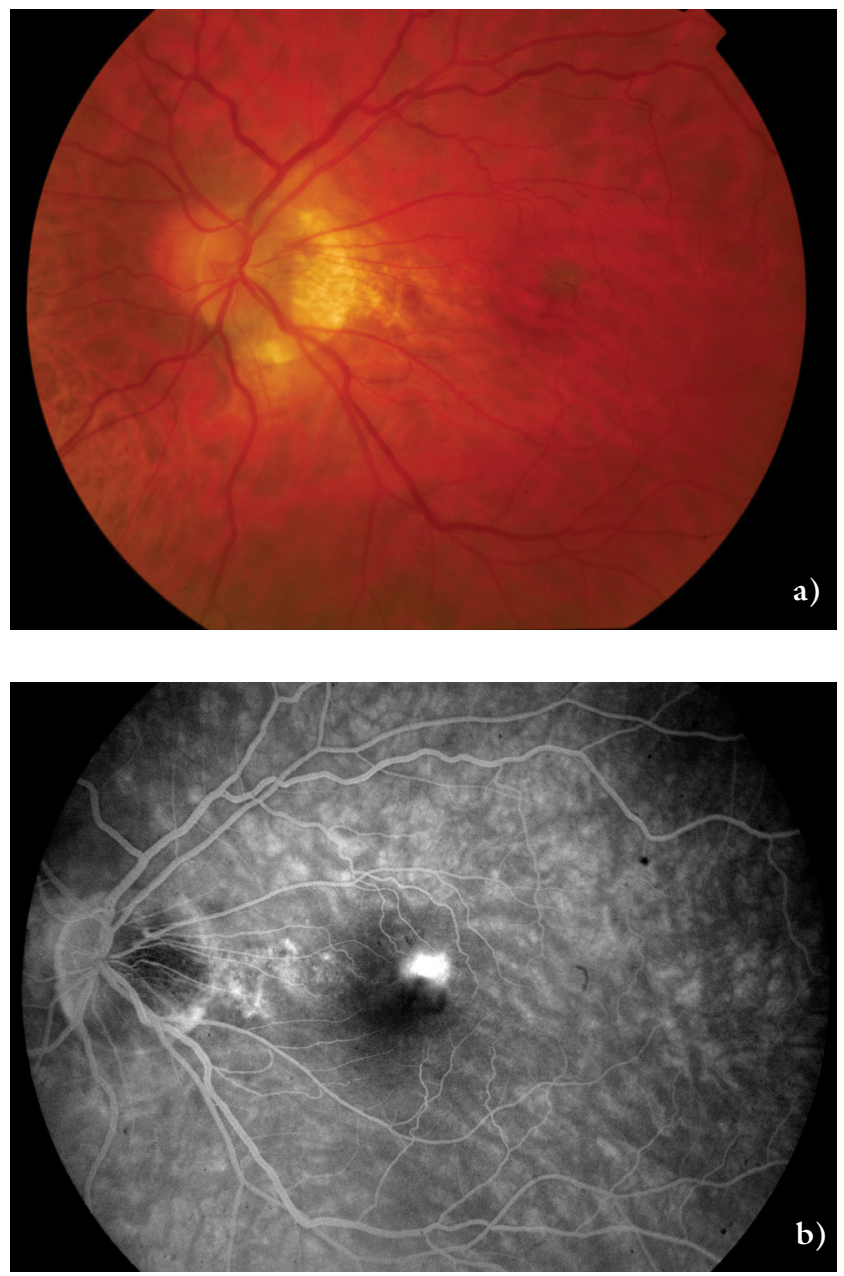

1. ábra $\quad$ a) Patológiás myopiában szenvedő egyik betegünk szemfenéki képe, amelyen látható a jellemző funduseltérések közül a széles peripapillaris atrophiás sarló, valamint a myopiás maculopathia. b) Ugyanezen betegünk szemfenéki fluoreszcens angiográfiás felvétele, amelyen szivárgás figyelhető meg a chorioidea-neovascularisatiós laesio területén 
stresszt gyakorol a retinára, beleértve a retinalis pigmentepithelsejteket is, amely in vitro kísérletek alapján az angiogén faktorok expressziójára és szekréciójára hatással van a VEGF-szint emelkedését eredményezve [16]. A heterodegeneratív elmélet ezzel szemben a háttérben nem mechanikus intrinszik biológiai okokat feltételez, ezzel összhangban állnak azok a tanulmányok, amelyek a myopiás CNV genetikai hátterét hangsúlyozzák [17]. A harmadik elmélet szerint a chorioideakeringés hemodinamikájának változása állhat a CNV kialakulásának hátterében.

A myopia talaján kifejlődött CNV kezelésére többféle terápiát alkalmaztak az elmúlt évtizedben, különböző sikerrel (termális lézerfotokoaguláció, verteporfirin PDT, submacularis mútét) [18]. A fotodinámiás terápia verteporfirinnal (vPDT) volt az első bizonyítottan hatékony kezelés myopiás CNV-ben, de ez a módszer csak stabilizálta a visust, szignifikáns javulást nem lehetett elérni [19]. Az intravitrealis anti-VEGF-injekció alkalmazása jelentette a legújabb terápiás lehetőséget myopiás $\mathrm{CNV}$ ben, az első közlések 2006-ban születtek [20,21]. A kezelés biztonságosnak bizonyult, és ezzel már szignifikáns látásjavulást lehetett elérni, ezért az anti-VEGF-terápia lett (és jelenleg is az) a myopiás CNV első vonalbeli kezelése [22].

A RADIANCE tanulmány volt az első hármas fázisú randomizált, kontrollált vizsgálat, amely összevetette a ranibizumab- és a PDT-kezelés hatékonyságát és biztonságosságát myop betegeknél kialakult CNV-ben [23]. A vizsgálatban a betegeket három csoportba osztották randomizált módon. Az első csoportba tartozók az első napon és egy hónap múlva kaptak ranibizumabinjekciót, a továbbiakban pedig a látóélesség alakulásától függően. A második csoportba tartozók konzekvensen az első napon kaptak ranibizumabkezelést, a későbbiekben csak akkor, amennyiben a betegség aktivitást mutatott (intraretinalis vagy subretinalis folyadék vagy aktív szivárgás). A harmadik csoport fotodinámiás kezelésben részesült, de a harmadik hónaptól már ranibizumabinjekciót is kaphattak. A tanulmány elsőként igazolta, hogy az intravitrealis ranibizumabkezelés hatékonyabb a PDT-kezelésnél, akár a látóélesség változása, akár a betegség aktivitása alapján történik a kezelés. A VEGF-gátló kezeléssel átlagosan 10-nél több ETDRS-betü-javulást tapasztaltak három hónap után, szemben a PDT-kezeléssel, ahol átlagosan két betú volt a javulás. Ez a javulás a 12. hónap végéig fenntartható volt. Azoknál a betegeknél, akik a kezdeti PDT-kezelést követően a harmadik hónap után ranibizumabkezelést kaptak, szintén visusjavulás volt tapasztalható ( $+9,3$ betû), bár ez kisebb mértékű volt azoknál, akik kezdettől a VEGF-gátló injekcióban részesültek. Ebből arra lehetett következtetni, hogy myopiás CNV-ben szenvedő betegeknél fontos a ranibizumabkezelés mielőbbi megkezdése. Vizsgálták az átlagos injekciószámot is a különböző csoportokban, és azt tapasztalták, hogy annál a csoportnál, ahol a betegség aktivitása alapján döntöttek az újrakezelésről, kevesebb injekcióra volt szükség (átlagosan 3,5) szemben az első csoporttal (átlagosan 4,6), viszont a látóélesség tekintetében nem volt különbség.

Jelen vizsgálatunk célja az volt, hogy elemezzük az intravitrealis ranibizumabkezelés hatékonyságát patológiás myopia talaján kialakult $\mathrm{CNV}$-ben szenvedő betegeknél. Hazánkban a ranibizumab törzskönyvezett gyógyszer, amely jelenleg egyedi engedély alapján finanszírozott, és kijelölt centrumokban érhető el a betegek részére.

\section{Módszer}

Tanulmányunkban retrospektív módon vizsgáltuk patológiás myopia talaján kifejlődött chorioidea-neovascularisatióban szenvedő betegeknél az intravitrealis ranibizumabkezelés eredményességét. Összesen 14 myop beteg (12 nő, 2 férfi) 14 szemének adatait elemeztük. A betegek 2009 és 2015 között álltak kezelés alatt a Semmelweis Egyetem Szemészeti Klinikáján, Budapesten. Az intravitrealis injekció beadását hat különböző retinaspecialista végezte.

Minden betegnél teljes szemészeti vizsgálat történt, köztük a legjobb korrigált látóélesség vizsgálata ETDRStáblával kiinduláskor, valamint a kontrollok során. Minden alkalommal történt OCT-vizsgálat, amellyel meghatároztuk a chorioidea-neovascularisatiós laesio magasságát, ezenkívül minden betegnél történt fluoreszcein angiográfiás vizsgálat a terápia megkezdése előtt. A visus vizsgálatakor a négy méterről olvasott betűk számát vettük figyelembe, a laesio magasságát mikrométerben adtuk meg. Az intravitrealis ranibizumab adása pro re nata (szükség szerinti) kezelési móddal történt. Elemeztük a beadott injekciók számát, valamint feljegyeztük az esetleges intra-, illetve posztoperatív mütéti szövődményeket.

Elsődleges célunk az volt, hogy a látóélesség, illetve a CNV-laesio nagyságának változásán keresztül vizsgáljuk az intravitrealis VEGF-gátló kezelés hatékonyságát. Az eredményeket elemeztük emellett az életkor függvényében is, a betegeket két csoportra osztva (60 év felettiek, illetve alattiak). A statisztikai elemzés során Wilcoxon-tesztet használtunk a visus, illetve a CNV-laesio magasságváltozásának vizsgálatához. Vizsgáltuk a visusváltozást az életkor, illetve a kiindulási visus függvényében, ennek statisztikai elemzéséhez Spearman-féle rangkorrelációs tesztet használtunk. A statisztikai analízist Statistica 8.0 (StatSoft, Tulsa, OK, Amerikai Egyesült Államok) programmal végeztük. Minden esetben a $\mathrm{p}<0,05$ értéket tekintettük statisztikailag szignifikánsnak.

\section{Eredmények}

A vizsgálatunkban részt vevő 14 beteg átlagéletkora $61 \pm 17$ év volt (a legfiatalabb beteg 27 éves, a legidősebb beteg 88 éves volt). A betegek közül öt betegnél 


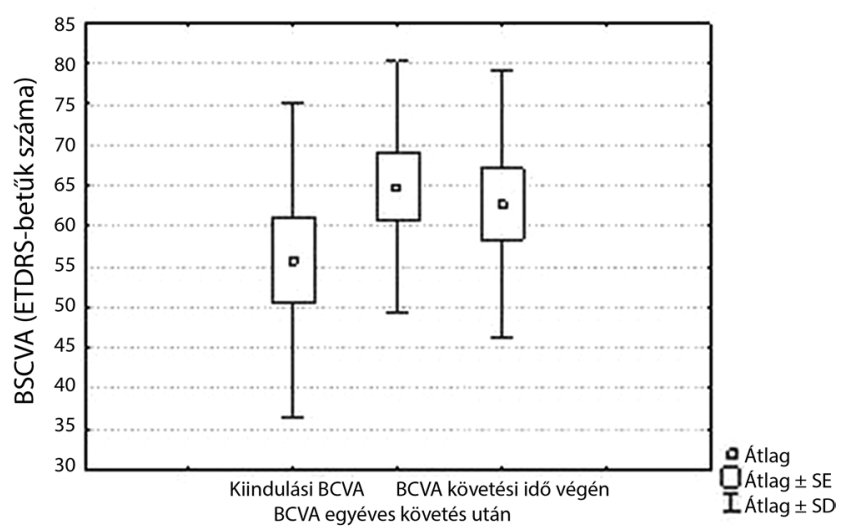

2. ábra $\quad$ A legjobb korrigált látóélesség változása egy év alatt, valamint az átlagos követési idő végére

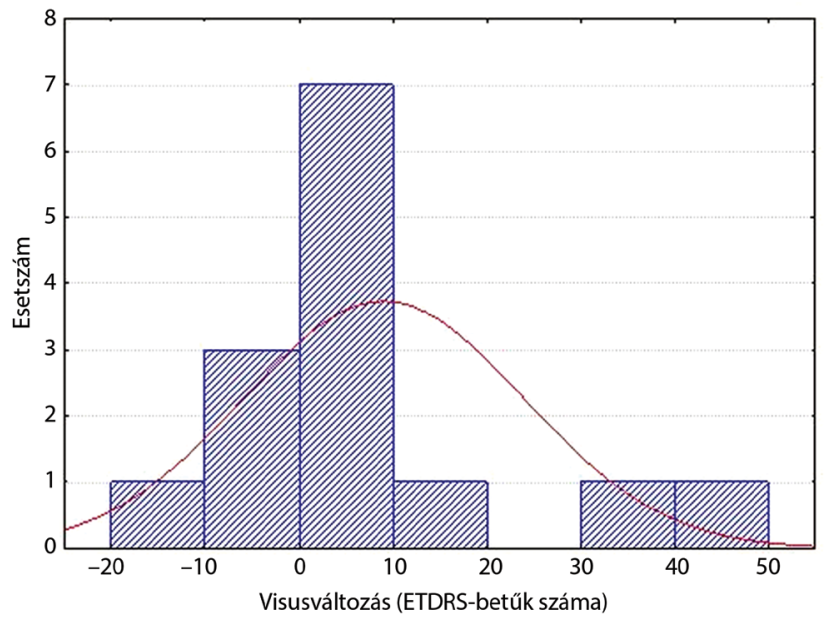

3. ábra $\quad$ A látóélesség-változás eloszlása az első év végén

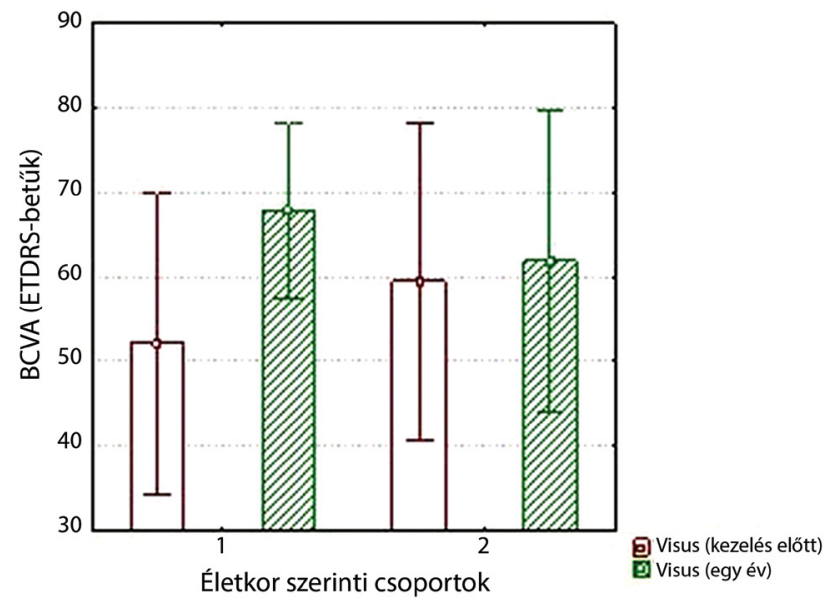

4. ábra $\mid$ A 60 év alattiaknál (1. csoport), illetve a 60 év felettieknél (2. csoport) tapasztalt egy év alatti visusváltozás

történt korábban szürkehályog-mútét, ebből egy betegnél szerepel az anamnézisben kombinált mütét vitrectomiával ideghártya-leválás miatt. Két beteg anamnézisében szerepelt látásjavító lézeres szemmútét (fotorefraktív

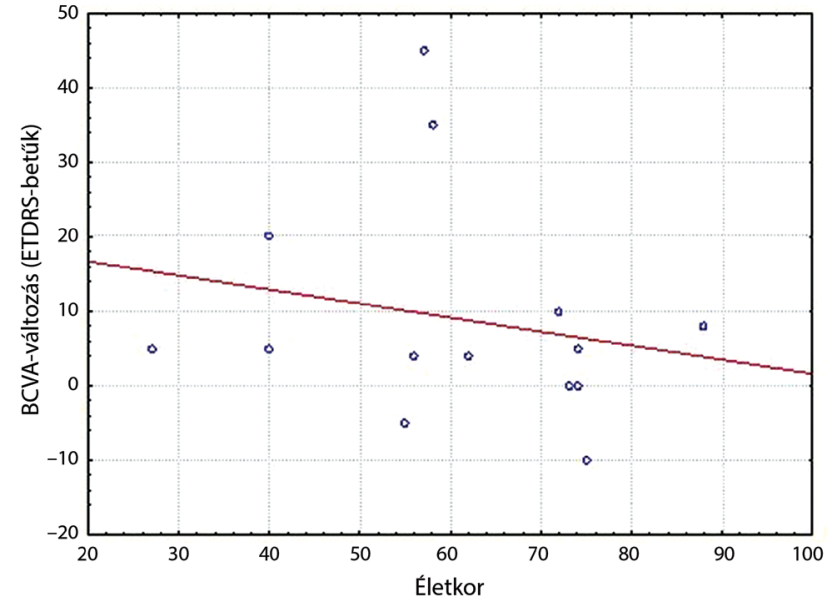

5. ábra |A visusváltozás és az életkor közötti korreláció $(\mathrm{p}=0,3941)$

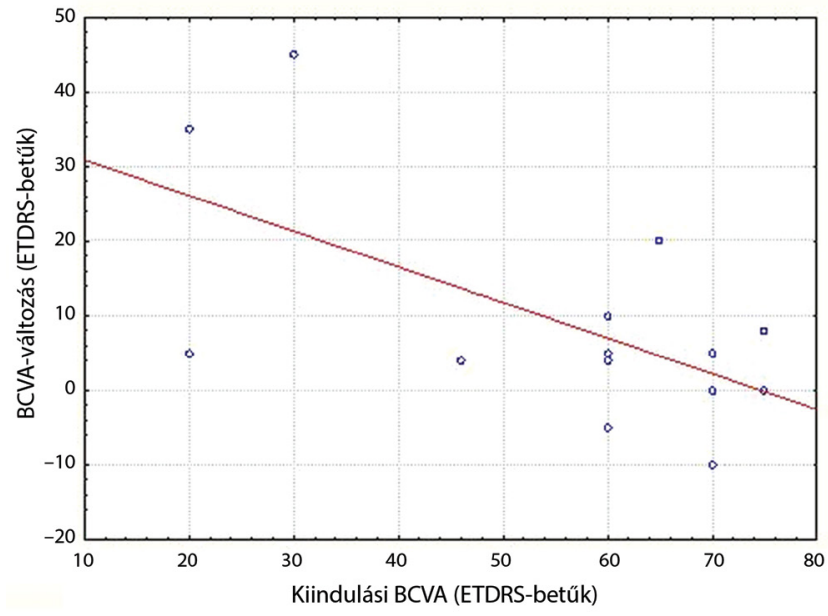

\begin{tabular}{l|l} 
6. ábra & $\left.\begin{array}{l}\text { A visusváltozás és a kiindulási visus közötti korreláció } \\
0,1407\end{array}\right)$
\end{tabular}

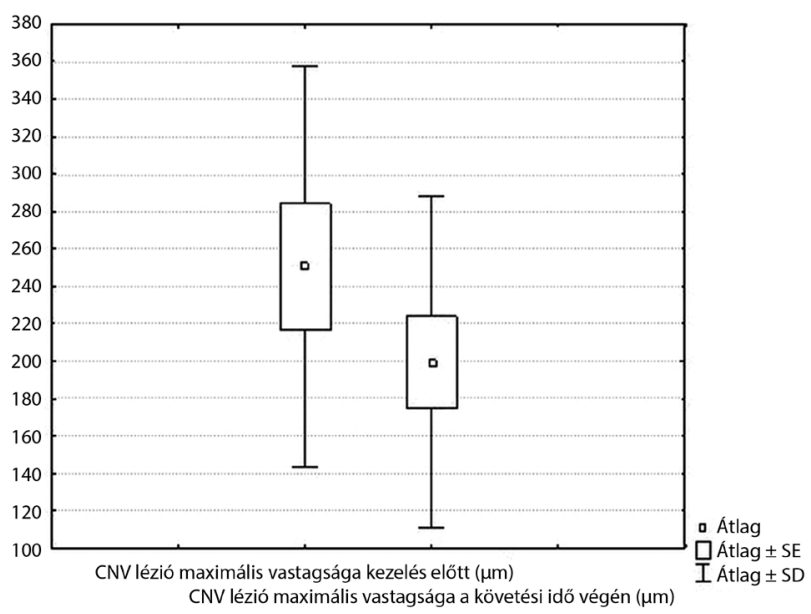

7. ábra $\quad$ A chorioidea-neovascularisatiós laesio magasságának változása a követési idő végére

keratectomia). Egyik betegünk sem szenvedett glaucomában. Az általános anamnézisből az inzulinnal kezelt cukorbetegség emelendő ki, ez egy betegünket érintette. Az átlagos fénytörési hiba (szférikus ekvivalensben meg- 
adva) $-12,1 \pm 8,9$ D volt, a legkisebb érték $-1,0$ D volt (az egyik, PRK-n átesett betegünk refrakciója), a legnagyobb érték $-26,0 \mathrm{D}$ volt. Az átlagos követési idő $19,7 \pm 23,9$ hónap volt.

A kiindulási visusérték betegeinknél ETDRS-betúkben megadva átlagosan $55,8 \pm 19,3$ betü volt, ez az első év végére $64,8 \pm 15,5$ betưre változott, a követési idő végén $62,6 \pm 16,32$ betü volt (2. ábra). Az első év végére 10 betegnél javulást tapasztaltunk, két betegnél nem változott a látóélesség, két betegnél romlott. A látóélesség-változás eloszlása az első év végén a 3. ábrán látható. A követési idő végére nyolc betegnél javult a visus, két betegnél nem változott, négy betegnél romlott.

A változás az első év végére szignifikánsnak bizonyult (Wilcoxon-teszt, $\mathrm{p}=0,0414$ ), a kiindulási visust összevetve a követési idő végi eredményekkel, a változás nem volt szignifikáns (Wilcoxon-teszt, $\mathrm{p}=0,2896$ ).

A betegeket vizsgáltuk életkoruk alapján két csoportba osztva: az első csoportba a 60 év alattiak (hét beteg), a második csoportba a 60 év felettiek tartoztak (hét beteg). Az átlagos látóélesség az első csoportban 52,1 betưről az első év végére 67,7 betûre, a követési idő végére 63,6 betüre változott. A második csoportban a kiindulási átlagos visus 59,4 betű volt, ez az első év végére 61,9, a követési idő végére 61,7 betüre változott (4.ábra).

Vizsgáltuk az egyéves követés alatti visusváltozás és az életkor közötti összefüggést: a két változó között nem találtunk statisztikailag szignifikáns korrelációt ( $\mathrm{p}=$ 0,3941) (5. ábra). Nem volt szignifikáns a kapcsolat méréseink szerint a kiindulási visus és az egy év alatti visusváltozás között sem $(\mathrm{p}=0,1407)$ (6. ábra).

A chorioidea-neovascularisatiós laesio magassága kiinduláskor átlagosan $250 \pm 107 \mu \mathrm{m}$ volt, ez a követési idő végére $199 \pm 89 \mu \mathrm{m}$-re csökkent, a változás statisztikailag szignifikánsnak bizonyult $(\mathrm{p}=0,0125)$ (7. ábra).

Betegeink az elsó évben átlagosan 1,8 $\pm 1,1$ injekciót kaptak, a követési idő alatt összesen átlagosan 2,8 $\pm 2,1$ injekcióban részesültek (a legkevesebb egy, a legtöbb nyolc injekció volt). A kezdeti első injekciót leszámítva, amelyet minden beteg megkapott, a betegek átlagosan egy további injekcióban részesültek.

Súlyosabb szövődmény a 14 betegből egy betegnél jelentkezett a követési idő alatt, nála az injekció beadását követően három hónappal ideghártya-leválás alakult.

\section{Megbeszélés}

A myopia talaján kialakuló CNV-ben az intravitrealis VEGF-gátló injekció adása bizonyult eddig a leghatékonyabb kezelésnek. A kedvező eredményeket már több különböző munkacsoport publikálta, jelen közlemény az első hazai eredményeket mutatja be.

$\mathrm{Az}$ első nagyobb prospektív, multicentrikus tanulmány, amely a VEGF-gátlók közül a ranibizumabot vizsgálta, a REPAIR tanulmány volt [24]. Összesen 65 beteg részvételével 12 centrumban történt a vizsgálat. $\mathrm{Az}$ első eredmények biztatóak voltak: a hatodik hónapra az átlagos visusjavulás 12,2 betû volt (ETDRS-táblán), a centrális maculavastagság $108 \mu \mathrm{m}-\mathrm{t}$ csökkent, mindehhez átlagban 2,9 injekció adására volt szükség. A 12 hónapos eredmények [25] hasonlóan biztatóak voltak, az átlagos látóélesség-javulás az elsô év végére 13,8 betû volt, a centrális maculavastagság 135 mikrométerrel lett kevesebb, az átlagos injekciószám 3,6 volt. Szövődmény mindösszesen egy esetben jelentkezett (endophthalmitis), ideghártya-leválás nem fordult elő a 12 hónap alatt.

Más VEGF-gátló szerekkel szintén pozitív eredményeket értek el myopiás CNV-ben. Egy retrospektív, multicentrikus tanulmány az intravitrealis bevacizumabot hasonlította össze ranibizumabbal egyéves követési idő alatt [26]. Mindkét hatóanyag esetében statisztikailag szignifikáns javulást tapasztaltak mind a legjobb korrigált látóélességet, mind a centrális fovealis vastagságot illetően, a két csoport értékei között nem volt szignifikáns különbség. Egy év alatt az átlagos injekciószám 2,43 , illetve 2,72 volt a két csoportban, a különbség itt sem volt szignifikáns statisztikai szempontból.

A MYRROR tanulmány az intravitrealis aflibercept, egy új rekombináns fúziós protein hatását vizsgálta myopiás CNV-ben, egy multicentrikus, III. fázisú, nemzetközi vizsgálatban [27]. A 24. hét végére szignifikáns javulást tapasztaltak a legjobb korrigált látóélességet illetően (átlagosan $+12,1$ betû), összevetve a placebocsoporttal (átlagosan $-2,0$ betú). A 48 . hét végén az átlagos javulás 13,5 betû volt, szemben a másik csoporttal, akik a 20. hét után már részesülhettek afliberceptinjekcióban, náluk az átlagos javulás $+3,9$ betû volt. Ebből a myopiás CNV diagnózis utáni mielőbbi kezelésének jelentőségére lehetett következtetni. Az átlagos injekciószám 48 hét alatt 3,0 injekció volt, az első nyolc hétben 2,0 volt. Öszszefoglalva: Az intravitrealis aflibercept is hatékony kezelésnek bizonyult myopiás CNV-ben, amellyel gyorsan javulást lehet elérni. Ez a látóélesség a későbbiekben megőrizhető viszonylag kevés, főként a korai szakban adott injekcióval.

Neelam és mtsai egy összefoglaló közleményben ismertették a myopiás CNV természetes lefolyását és hoszszabb távú következményeit az eddigi eredmények alapján [10]. Úgy tűnik, a kezdeti stádiumban a myopiás CNV egy önmagától ,gyógyuló” állapot, szemben más eredetű, például AMD talaján kialakuló CNV-vel. A kezdeti hirtelen látásromlást követően a visus viszonylag gyorsan stabilizálódik, ezt azonban a regrediált CNV körüli progresszív chorioretinalis atrophia kifejlődése követi, amely a későbbi látásromlás kialakulásában alapvető szerepet játszik. Több tényező befolyásolja a végső látóélességet, ezek közül a legfontosabb az életkor a CNV kialakulásakor. Az idősebb életkorral együtt járó retinalis pigmentepithel-diszfunkció akadályozza a CNV növekedésének megfékezését, másrészt a korral az egyéb társbetegségek (mint az AMD) előfordulása is gyakoribb. Mindezek alapján a myopiás CNV-ben alkalmazott VEGF-gátló gyógyszerek hosszabb távú hatásának vizsgálata is jelentőséggel bír. 
Ruiz-Moreno és mtsai [28] a myopiás CNV-ben szenvedő betegek anti-VEGF-kezelésének (bevacizumab, illetve ranibizumab) eredményeit foglalták össze egy retrospektív, multicentrikus tanulmányban hatéves követési idő alatt. Ezen idő alatt a betegeknek - a mi vizsgálatainkhoz hasonlóan - átlagosan 3,3 $\pm 2,3$ injekcióra volt szüksége. Az átlagos kiindulási visus 56,7 betûról a 12 . hónapra 65,7 betüre változott $(\mathrm{p}<0,001)$, a 24 . hónapra 63,6 betüre ( $\mathrm{p}=0,001)$, a követési idő végére pedig 58,4 betűre $(\mathrm{p}=0,5)$. A betegek átlagéletkora 56,5 év volt. Vizsgálták a követési idő végi visusjavulás és a kiindulási visus, valamint az életkor közötti összefüggést is, mindkét esetben statisztikailag szignifikáns negatív korrelációt találtak a változók között. Összefoglalva: Úgy találták, anti-VEGF-kezeléssel szignifikáns javulást lehet elérni az első három évben, a javulás a következő három évben nem szignifikáns, ez pedig a nagyfokú myopia természetes lefolyásának, az atrophia kialakulásának tudható be, terápiától függetlenül.

Oishi és mtsai [29] myopiás CNV-ben szenvedő betegeknél vizsgálták a chorioretinalis atrophia hosszú távú progresszióját anti-VEGF-kezelés mellett. Négyéves követési idő alapján igazolódott, hogy a legtöbb betegnél $(72,7 \%)$ progrediál a chorioretinalis atrophia, amely a végső látóélességre is hatással van, ez a betegség természetes lefolyásának tudható be, nem a kezelés következményének. A látóélesség ennek megfelelően alakult: az első három évben megfigyelhető volt szignifikáns javulás (bár a kezdeti javulást követően enyhe csökkenés volt látható), a negyedik év végén már nem volt a javulás statisztikailag szignifikáns.

Saját, myopiás CNV-vel kezelt betegeinknél statisztikailag szignifikáns javulást tapasztaltunk egy év után a látóélességet illetően, az átlagos visusjavulás +9 ETDRSbetû volt. Hazai eredményeink tükrözik a nemzetközi vizsgálatok eredményeit [23-27], myopiás CNV-ben intravitrealis anti-VEGF adásával gyors és szignifikáns javulást lehet elérni az első évben. Az általunk tapasztalt egy év alatti látóélesség-javulás mértéke elmarad az említett nagyobb vizsgálatok eredményeitől (RADIANCE tanulmány: a kezdettől ranibizumabbal kezelt csoportokban: $+13,8$, illetve $+14,4$ betü; REPAIR tanulmány: $+13,8$ betü). Ez magyarázható a vizsgált betegeink némileg magasabb átlagéletkorával (6l év), szemben a másik két tanulmányban részt vevơk átlagéletkorával (RADIANCE tanulmány: a kezdettől ranibizumabbal kezelt csoportokban: 54,0, illetve 56,1 év; REPAIR tanulmány: 56,8 év). Egy összefoglaló közlemény több tanulmány eredményei alapján leírja, hogy idősebb, myopiás CNV-ben szenvedő betegeknél az anti-VEGFkezelés mellett rosszabb prognózis várható, szemben a fiatalabb korcsoporttal [30]. Myopiás CNV esetén a legjobb eredményeket a mielőbbi, korai anti-VEGF-kezelés mellett tapasztalhatjuk, ahogy a RADIANCE tanulmány eredményei is mutatják. Betegeink azonban sok esetben csak késéssel kerülnek a megfelelő centrumba, ahol a szükséges kezelést megkaphatják, ez pedig szintén magyarázhatja a kisebb mértékű javulást. További ok lehet az első évi viszonylag alacsony átlag-injekciószám $(1,8)$, amely kevesebb mind a $\operatorname{REPAIR}(3,6)$, mind a RADIANCE $(4,6$, illetve 3,5$)$ tanulmányban egy év alatt adott kezelések számához képest. Más tanulmányokban a mi eredményeinkhez hasonló volt az egy év alatti visusjavulás mértéke $[28,31]$.

Vizsgáltuk az egy év utáni eredményeket is, az átlagos követési idő 19,7 hónap volt, amelynek végére átlagosan $+6,8$ betű javulást tapasztaltunk, bár ez statisztikai szempontból nem volt szignifikáns. Négy betegnél a kezelés ellenére romlott a visus. Más szerzők is leírták hasonló követési idő alatt tapasztalt eredményeiket. Iacono és $m$ tsai [32] átlagosan 18 hónapos követés alatt intravitrealis ranibizumab, valamint bevacizumab adása mellett átlagosan 1,7, illetve 1,8 sor javulást tapasztaltak. Egy másik tanulmányban [33] bevacizumabkezelés mellett az átlagos legjobb korrigált visus 54,8 betüről a 24 . hónap végére 59,25 betưre változott, szignifikáns változást csak az egy hónapos kontrollnál tapasztaltak. Ruiz-Moreno és mtsai [28], a korábban említetteknek megfelelóen, a hat év alatti eredményeket vizsgálták, a 24 . hónap végére az átlagos látóélesség 56,7 betûról 63,6 betűre változott. $\mathrm{Az}$ eredményeket összevetve azt figyelhetjük meg, hogy hosszabb távon (kétéves eredményeket figyelembe véve) bár az átlagos látóélesség javulást mutat, azonban ez nem éri el az első év során elért javulás mértékét, amely a fentiekre utalva a myopiás CNV természetes lefolyásának, a chorioretinalis atrophia kifejlődésének tudható be. Ez magyarázhatja a kezelés ellenére fellépő visusromlást is. Bár szignifikáns javulást nem tapasztaltunk, eredményeink és a nemzetközi szakirodalom alapján is hosszabb távon (19,7 hónap) stabilizálható a visus intravitrealis injekciós kezelés mellett myopiás CNV-ben. Mindezt kevés, mindösszesen átlagosan 2,8 injekció adása mellett. A funkcionális eredményekkel összhangban áll, hogy a követési idő végére statisztikailag szignifikánsan csökkent a CNV-laesio magassága.

Vizsgáltuk az egy év alatti visusváltozás és az életkor, valamint a kiindulási visus közötti összefüggéseket, de korreláció nem volt kimutatható. Megfigyeltük viszont, hogy míg a 60 év felettiek csoportjában az egy év alatti visusjavulás átlagosan mindösszesen $+2,5$ betü volt, addig a 60 év alattiak csoportjában átlagosan jóval jelentősebb, $+15,6$ betú javulást tapasztaltunk. Érdekes az is, hogy bár korreláció nem volt kimutatható, abban a csoportban, ahol kisebb volt a kiindulási visus (60 év alattiak, 52,1 betú), jóval nagyobb mértékú volt a javulás, mint a másik csoportban (60 év felettiek, 59,4).

Vizsgálták a nemzetközi irodalomban is a fenti összefüggéseket. Ruiz-Moreno és mtsai eredményei [28] alapján szignifikáns negatív korreláció áll fenn a visusjavulás és az életkor (50 év alattiak és 50 év felettiek), valamint a kiindulási visus között a hatéves követés alatt. Cohen és mtsai [34] csak a kiindulási visus és látásjavulás mértéke között találtak statisztikailag szignifikáns összefüggést, a kiindulási visus és életkor között nem. Más szerzők [35] 
hasonlóan szignifikáns összefüggést találtak a kiindulási visus és a visusváltozás között, a kiindulási visus és az életkor között viszont nem. Ez utóbbit azzal magyarázták, hogy betegeik döntő többsége 60 év feletti volt. Összefoglalva: A kiindulási visus és a visusváltozás között a fenti tanulmányok mindegyike talált szignifikáns összefüggést, az életkor és a visusváltozás közötti korreláció fennállása nem egységes. Mi nem találtunk a fenti változók között korrelációt, ennek hátterében állhat a többi tanulmányhoz képest kisebb esetszám, de a megfigyeléseink mégis azt mutatják, hogy a fiatalabbaknál, illetve alacsonyabb kiindulási visus esetén nagyobb mértékű látásjavulás várható.

A követési idő alatt mindössze egy esetben tapasztaltunk szövődményt (ideghártya-leválás), a kezelés biztonságosnak bizonyult. Myopiás CNV kezelésénél érdemes azonban figyelembe vennünk, hogy ebben az indikációban magasabb az ideghártya-leválás kockázata.

\section{Következtetés}

Az intravitrealis VEGF-gátló adása myopia talaján kifejlődött chorioidea-neovascularisatióban hatékony kezelési mód, kevés injekció adásával javulás érhető el. Hoszszabb távon elsősorban a visus stabilizációja biztosítható a kezeléssel, néhány betegnél pedig kezelés ellenére romolhat a látóélesség.

Anyagi támogatás: A szerzők anyagi támogatásban nem részesültek.

Szerzői munkamegosztás: P. A., Sz. A., R. M., B. Gy., E. M., Sz. Zs., N. Z. Zs.: A betegvizsgálat végzése. S. G.: Adatrögzítés. S. G., P. A., L. R.: Képelemzés. R. M., S. G.: Statisztikai elemzés. L. R., R. M., S. G., P. A., N. Z. Zs.: A kézirat és az ábrák elkészítése. A közlemény végleges változatát mindegyik szerző elolvasta és jóváhagyta.

Érdekeltségek: A közlemény vonatkozásában a szerzőknek nincsenek anyagi érdekeltségeik.

\section{Irodalom}

[1] Wong, T. Y., Ferreira, A., Hughes, R., et al.: Epidemiology and disease burden of pathologic myopia and myopic choroidal neovascularization: an evidence-based systematic review. Am. J. Ophthalmol., 2014, 157(1), 9-25.el2.

[2] Klaver, C. C., Wolfs, R. C., Vingerling, J. R., et al.: Age-specific prevalence and causes of blindness and visual impairment in an older population: the Rotterdam Study. Arch. Ophthalmol., 1998, 116(5), 653-658.

[3] Cedrone, C., Nucci, C., Scuderi, G., et al.: Prevalence of blindness and low vision in an Italian population: a comparison with other European studies. Eye, 2006, 20(6), 661-667.

[4] Kiss, H., Németh, J.: Causes of blindness in Hungary. [A vakság okai Magyarországon.] Szemészet, 2013, 150(3), 103-110.

[5] Lukács, R., Resch, M., Kiss, H., et al.: Cataract surgery in intravitreal ranibizumab injection-treated patients with age-related mac- ular degeneration. [Szürkehályog-mútét időskori macula dege neráció miatt intravitreális ranibizumab injekcióval kezelt betegeken]. Szemészet, 2013, 150(1), 19-23.

[6] Lukács, R., Resch, M., Papp, A., et al.: Long term intravitreal ranibizumab treatment for exsudative age-related macular degeneration [Hosszú távú intravitrealis ranibizumabkezelés exsudativ időskori maculadegenerációban.] Orv. Hetil., 2013, 154(45), 1790-1797.

[7] Chan, W. M., Ohji, M., Lai, T. Y., et al.: Choroidal neovascularization in pathological myopia: an update in management. Br. J. Ophthalmol., 2005, 89(11), 1522-1528.

[8] Verteporfin in Photodynamic Therapy Study Group: Photodynamic therapy of subfoveal choroidal neovascularization in pathologic myopia with verteporfin. 1-year results of a randomized clinical trial - VIP report no. 1. Ophthalmology, 2001, 108(5), 841852.

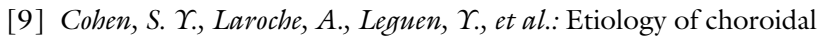
neovascularization in young patients. Ophthalmology, 1996, $103,1241-1244$

[10] Neelam, K., Cheung, C. M., Ohno-Matsui, K., et al.: Choroidal neovascularization in pathological myopia. Prog. Retin. Eye Res., 2012, 31(5), 495-525.

[11] Fredrick, D. R.: Myopia. BMJ, 2002, 324(7347), 1195-1199.

[12] Miller, D. G., Singerman, L. J.: Natural history of choroidal neovascularization in high myopia. Curr. Opin. Ophthalmol., 2001, $12(3), 222-224$.

[13] Ohno-Matsui, K., Kawasaki, R., Jonas, J. B., et al.: International photographic classification and grading system for myopic maculopathy. Am. J. Ophthalmol., 2015, 159(5), 877-883.e7.

[14] Ohno-Matsui, K., Lai, T. Y., Lai, C. C., et al.: Updates of pathological myopia. Prog. Retin. Eye Res., 2016, 52, 156-187.

[15] Wong, T. J., Ohno-Matsui, K., Leveziel, N., et al.: Myopic choroidal neovascularisation: current concepts and update on clinical management. Br. J. Ophthalmol., 2015, 99(3), 289-296.

[16] Seko, Y., Seko, Y., Fujikura, H., et al.: Induction of vascular endothelial growth factor after application of mechanical stress to retinal pigment epithelium of the rat in vitro. Invest. Ophthalmol. Vis. Sci., 1999, 40(13), 3287-3291.

[17] Young, T. L.: Dissecting the genetics of human high myopia: a molecular biologic approach. Trans. Am. Ophthalmol. Soc., 2004, 102, 423-446.

[18] Lai, T. Y., Cheung, C. M.: Myopic choroidal neovascularization: Diagnosis and treatment. Retina, 2016, 36(9), 1614-1621.

[19] Blinder, K. J., Blumenkranz, M. S., Bressler, N. M., et al.: Verteporfin therapy of subfoveal choroidal neovascularization in pathologic myopia: 2-year results of a randomized clinical trial - VIP report no. 3. Ophthalmology, 2003, 110(4), 667-673.

[20] Laud, K., Spaide, R. F., Freund, K. B., et al.: Treatment of choroidal neovascularization in pathologic myopia with intravitreal bevacizumab. Retina, 2006, 26(8), 960-963.

[21] Tewari, A., Dhalla, M. S., Apte, R. S.: Intravitreal bevacizumab for treatment of choroidal neovascularization on pathologic myopia. Retina, 2006, 26(9), 1093-1094.

[22] Cohen, S. Y.: Anti-VEGF drugs as the 2009 first-line therapy for choroidal neovascularization in pathologic myopia. Retina, 2009, 29(8), 1062-1066.

[23] Wolf, S., Balciuniene, V. J., Laganovska, G., et al.; RADIANCE Study Group: RADIANCE: A randomized controlled study of ranibizumab in patients with choroidal neovascularization secondary to pathologic myopia. Ophthalmology, 2014, 121(3), 682-692.e2.

[24] Tufail, A., Patel, P. J., Sivaprasad, S., et al.: Ranibizumab for the treatment of choroidal neovascularization secondary to pathological myopia: interim analysis of the REPAIR study. Eye, 2013, 27(6), 709-715.

[25] Tufail, A., Narendran, N., Patel, P. J., et al.: Ranibizumab in myopic choroidal neovascularization: the 12 -month results from 
the REPAIR study. Ophthalmology, 2013, 120(9), 1944-1945. el.

[26] Cha, D. M., Kim, T. W., Heo, J. W., et al.: Comparison of 1-year therapeutic effect of ranibizumab and bevacizumab for myopic choroidal neovascularization: a retrospective, multicenter, comparative study. BMC Ophthalmology, 2014, 14, 69.

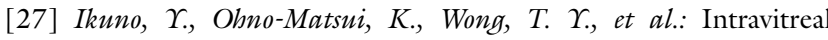
aflibercept injection in patients with myopic choroidal neovascularization: the MYRROR study. Ophthalmology, 2015, 122(6), $1220-1227$.

[28] Ruiz-Moreno, J. M., Montero, J. A., Araiz, J., et al.: Intravitreal anti-vascular endothelial growth factor therapy for choroidal neovascularization secondary to pathologic myopia. Six years outcome. Retina, 2015, 35(12), 2450-2456.

[29] Oishi, A., Yamashiro, K., Tsujikawa, A., et al.: Long-term effect of intravitreal injection of anti-VEGF agent for visual acuity and chorioretinal atrophy progression in myopic choroidal neovascularization. Graefes Arch. Clin. Exp. Ophthalmol., 2013, 251(1), $1-7$.

[30] Adatia, F. A., Luong, M., Munro, M., et al.: The other CNVM: A review of myopic choroidal neovascularization treatment in the age of anti-vascular endothelial growth factor agents. Surv. Ophthalmol., 2015, 60(3), 204-215.
[31] Silva, R. M., Ruiz-Moreno, J. M., Rosa, P., et al.: Intravitreal ranibizumab for myopic choroidal neovascularization. 12-month results. Retina, 2010, 30(3), 407-412.

[32] Iacono, P., Parodi, M. B., Papayannis, A., et al.: Intravitreal ranibizumab versus bevacizumab for treatment of myopic choroidal neovascularization. Retina, 2012, 32(8), 1539-1546.

[33] Iacono, P., Parodi, M. B., Papayannis, A., et al.: Intravitreal bevacizumab therapy on an as-per-needed basis in subfoveal choroidal neovascularization secondary to pathological myopia: 2-year outcomes of a prospective case series. Retina, 2011, 31(9), 1841-1847.

[34] Cohen, S. Y., Nghiem-Buffet, S., Grenet, T., et al.: Long-term variable outcome of myopic choroidal neovascularization treated with ranibizumab. Jpn. J. Ophthalmol., 2015, 59(1), 36-42.

[35] Nakanishi, H., Tsujikawa, A., Yodoi, Ү., et al.: Prognostic factors for visual outcomes 2 -years after intravitreal bevacizumab for myopic choroidal neovascularization. Eye, 2011, 25(3), 375381.

(Lukács Regina dr., Kistarcsa, Semmelweis tér 1., 2143 e-mail: lukacs.regina85@gmail.com)

\section{A rendezvények és kongresszusok híranyagának leadása}

a lap megjelenése előtt legalább 40 nappal lehetséges, a 6 hetes nyomdai átfutás miatt. Kérjük megrendelőink szíves megértését.

A híranyagokat a következő címre kérjük: Orvosi Hetilap titkársága: edit.budai@akademiai.hu Akadémiai Kiadó Zrt. 